\title{
Kernel Weights of Triticum, Hordeum, Avena, Secale and Panicum Species can be used for Better Estimation of Importance of Different Cereal Species in Archaeobotanical Assemblages
}

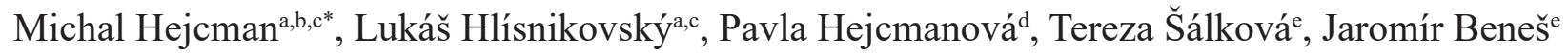 \\ ${ }^{a}$ Department of Ecology, Faculty of Environmental Sciences, Czech University of Life Sciences, Kamýcká 129, 16521 Prague 6 - Suchdol, Czech Republic \\ ${ }^{b}$ Department of Archaeology, Faculty of Arts, University of Hradec Králové, Rokitanského 62, 50003 Hradec Králové, Czech Republic \\ ${ }^{c}$ Crop Research Institute Prague - Ruzyně, Drnovská 507, 16106 Prague 6-Ruzynè, Czech Republic \\ ${ }^{d}$ Faculty of Tropical AgriSciences, Czech University of Life Sciences, Kamýcká 129, 165 21, Prague 6-Suchdol, Czech Republic \\ ${ }^{e}$ Laboratory of Archaeobotany and Palaeoecology, Faculty of Science, University of South Bohemia, Na Zlaté stoce 3, 370 05 České Budějovice, Czech Republic
}

\section{ARTICLE INFO}

\section{Article history:}

Received: $4^{\text {th }}$ March 2016

Accepted: $28^{\text {th }}$ December 2016

\section{Key words}

emmer wheat

einkorn

barley

millet

oats

macroremain analysis

\begin{abstract}
A BSTRACT
The importance of different cereals for human and animal nutrition in different historical periods has been frequently estimated according to the proportion of grains of individual cereal species from the total number of recorded grains in the archaeological assemblage. However, such presentations do not respect the differences in grain size among particular species. The aim of this study was to compare the kernel weights of cereal species planted in Europe since the Neolithic up to the first half of the $20^{\text {th }}$ century and to propose recalculation coefficients for their relevant comparison. Thousand kernel weights (TKW) of cereals were obtained from the Evigez database and from the available literature. Taking the TKW of Triticum aestivum (44.6 g) as 100\%, the descending order of cereal species in terms of their TKW in relation to T. aestivum was T. spelta $(100 \%)$, T. turgidum (99\%), hulled Hordeum vulgare (97\%), T. durum (92\%), T. dicoccum (88\%), naked H. vulgare (81\%), Secale cereale (79\%), T. dicoccoides (76\%), T. monococcum (67\%), hulled Avena sativa (66\%), naked A. sativa (64\%) and finally Panicum miliaceum (12\%). We recommend the use of these proposed recalculation coefficients for the comparison of proportions of cereal grains in archaeobotanical assemblages. The recalculated values better reflect the importance of the different cereal species for human economies and nutrition rather than simple proportions of the recorded grains of an individual species. The recalculation coefficients are particularly important in the case of a high proportion of $P$. miliaceum in an archaeological assemblage, as its grain size differs the most from the other frequently-recorded cereals.
\end{abstract}

\section{Introduction}

The grains of cereals belong to the most frequently recorded remains of cultural plants in archaeological assemblages. Since the start of agriculture in the European Neolithic up to Roman Times, the main cereals were hulled wheats, diploid Triticum monococcum (einkorn, 2n=14, Zaharieva, Monneveux 2014) and tetraploid T. dicoccum (emmer, $2 \mathrm{n}=28$, Kreuz et al. 2005; Zaharieva et al. 2010). Since the Neolithic or Bronze age, respectively, hulled and naked Hordeum vulgare (barley) together with Panicum milliaceum (common millet) were also commonly planted, and $T$.

*Corresponding author. E-mail: hejcman@fzp.czu.cz dicoccum was still the main staple crop (Hajnalová 1993; Bernardová et al. 2010; Š́lková et al. 2012; Festi et al. 2011; Zohary et al. 2012; Dreslerová et al. 2013). Hexaploid wheat species such as hulled $T$. spelta (spelt, $2 \mathrm{n}=42$ ) and naked T. aestivum (baker wheat, $2 \mathrm{n}=42$ ) appeared in central Europe from the Late Bronze Age (Beneš, Přikrylová 2008; Kočár, Dreslerová 2010). Since the La Tène period, the intentional planting of the formerly weedy cereal species Secale cereale (rye), Avena sativa (oat), and Hordeum vulgare (barley) became more common (Zohary et al. 2012; Dreslerová et al. 2013). Roman Times were characterised by the planting of $H$. vulgare, followed by T. dicoccum, Panicum, and by naked wheat (probably T. aestivum), Avena and Secale (Preiss et al. 2005; Dreslerová, Kočár 2013). From the Migration period, naked wheat ( $T$. aestivum the most probably) prevailed 
followed by Hordeum, Secale, Avena and T. dicoccum (Brombacher, Hecker 2015). At the start of the $20^{\text {th }}$ century, Secale was the main crop (having the largest cropping area in the Czech Republic), followed by Avena (Figure 1). The cropping area of T. aestivum and Hordeum was lower than half of the cropping area of Secale and Avena in the 1930s. The proportion of individual cereal crops completely changed after World Word II, and since the 1960s up to the present the main cereal crop has been $T$. aestivum followed by Hordeum; Avena and Secale have both become marginal crops with negligible cropping area. The planting of $T$. monococcum and $T$. dicoccum has completely disappeared. In the $21^{\text {st }}$ century, the renaissance of hulled wheat planting (T. monococcum, T. dicoccum and T. spelta) in Europe has been connected with the spread of organic farming and the increased interest in products with a high nutritional quality (Marino et al. 2009, 2011; Konvalina et al. 2012a). Although hulled Hordeum varieties dominate in contemporary Europe, hull-less (naked) varieties have been planted in the past and used for food production (Lister, Jones 2013). In central Europe, their planting was popular during the Bronze Age and then its use steeply declined (Š́lková et al. 2012). In northern Europe, naked barley represented approximately $50 \%$ of the Neolithic and Bronze Age barley records (Lister, Jones 2013). In mountain regions of Asia, such as the uplands of China, India, Nepal, Pakistan, Japan, both Koreas and Tibet, naked varieties of Hordeum are still planted and used as a staple crop for food production (Saisho, Purugganan 2007). In central Europe, naked barley was recorded as a relict of traditional mountain agriculture in an archaeobotanical assemblage from the $18^{\text {th }}$ century AD (Beneš, Kočár 2000).
The importance of different cereals for human and animal nutrition in different historical periods is a key point in archaeobotanical investigations, but there are vital methodological issues in its evaluation. It has been frequently estimated according to the proportion of grains of an individual cereal species from the total number of recorded grains in the archaeological assemblage. This is the simplest and most frequently-used way of presenting the data, but comes with low predictive value as to which cereal species are/were important for human and animal nutrition, thus making interpretations problematic. The problem with such a presentation is that it disregards the differences in grain size among particular species. For example, the grain of Panicum is much smaller than the grain of T. aestivum. The value of one Panicum grain for human nutrition is therefore substantially lower than the value of one grain of T. aestivum. To make an adequate comparison of the grains of different cereal species in archaeological assemblages, a recalculation of their numbers according to their importance for human nutrition or economy is necessary. The simplest way to do this is to use the kernel (grain) weights. In agronomy, a thousand kernel weight (TKW - the weight of a 1000 seeds) is one of the basic agronomic traits used to characterize the grain size of different crops and their varieties (e.g. Peleg et al., 2011; Guarda et al., 2004).

Taking account of the missing recalculation coefficients for the comparison of different cereals, the aim of this study was to compare the kernel weights of cereal species planted in Europe since the Neolithic up to the first half of the $20^{\text {th }}$ century and to propose recalculation coefficients for their relevant comparison. As an example, we then

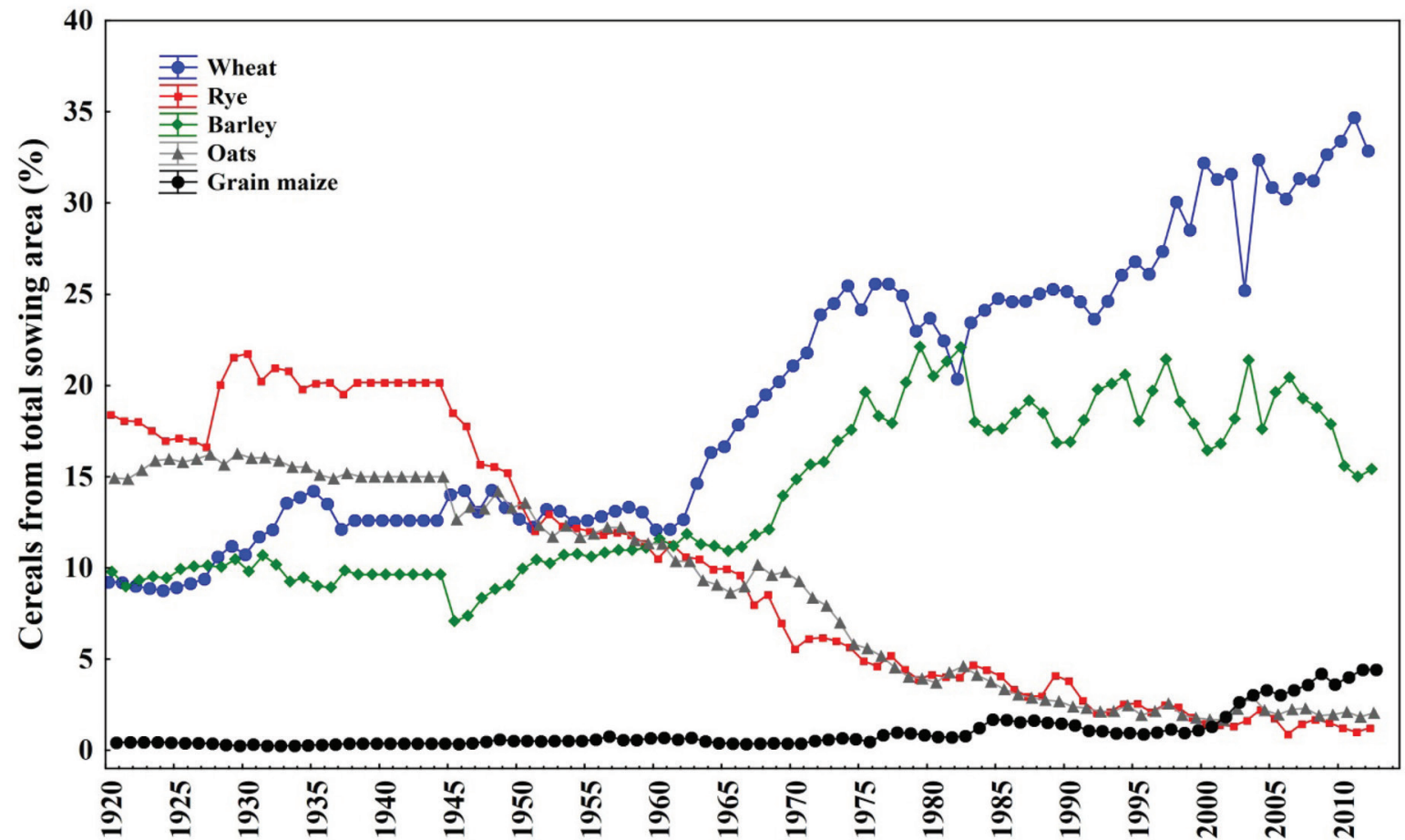

Figure 1. Proportion of cropping area of Triticum aestivum (wheat), Secale cereal (rye), Hordeum vulgare (barley), Avena sativa (oats) and Zea mays (grain maize) from total cropping area in the Czech Republic from 1920 to 2012 (according to Czech Statistical Office). 
used an archaeological assemblage from the Late Bronze Age to demonstrate the application and importance of the recalculation coefficient.

\section{Material and methods}

\subsection{Thousand kernel weights of different cereals and recalculation coefficients}

To provide a comparison of the kernel weights of cereal species planted in Europe since the Neolithic up to the first half of the $20^{\text {th }}$ century, we assembled data on about a thousand kernel weights (TKW) of old varieties of cereals registered up to $1960 \mathrm{~s}$ - as these would be minimally affected by modern breeding methods. In the case of marginal cereal species such as T. monococcum and T. dicoccum, we also used modern varieties as these have generally only been subjected to limited breeding in comparison to the frequently-planted T. aestivum with its many varieties. The TKW of cereals were obtained from the gene bank of the Crop Research Institute Prague - Ruzyně, the database Evigez (plant genetic resources documentation in the Czech Republic, http://genbank.vurv.cz/genetic/resources/asp2/default.htm) - and from the available literature (Codianni et al. 1996; Karagöz, Zencirci 2005; Troccoli, Codianni 2005; De Vita et al. 2006; Marino et al. 2009, 2011; Pagnotta et al. 2009; Ünal 2009; Brandolini et al. 2011; 2013; Arduiny et al. 2014). The TKW for each species was visualized in the form of frequency histograms in order to demonstrate the range of values and their distribution (Figures 2, 3 and 4). For each a)

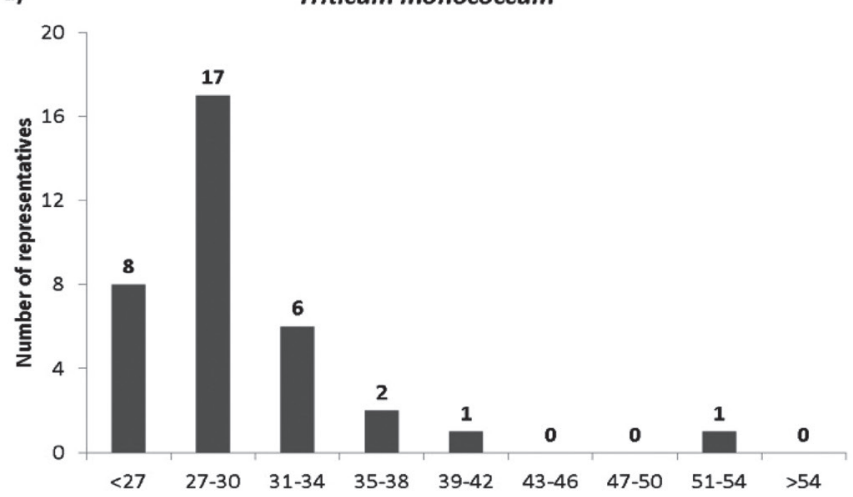

c)

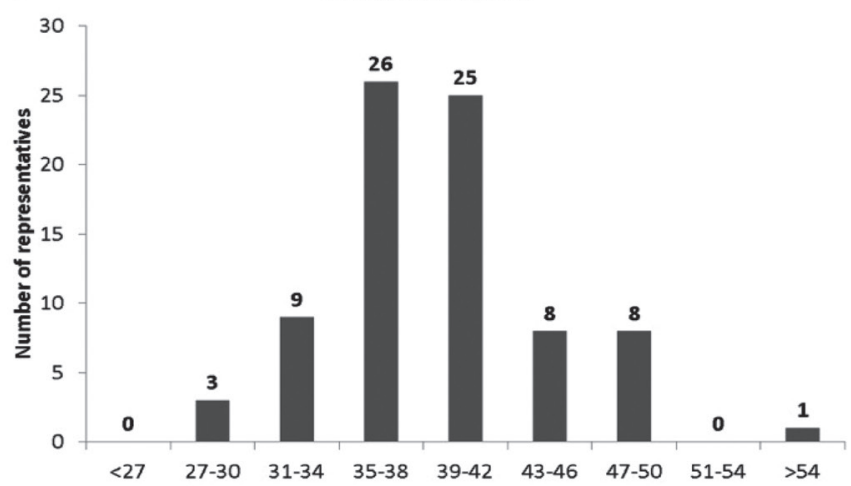

e)

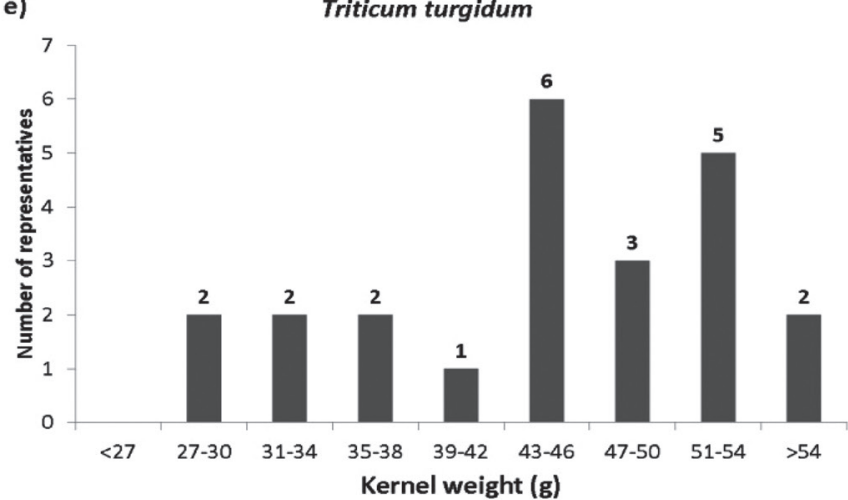

b)

Triticum dicoccoides

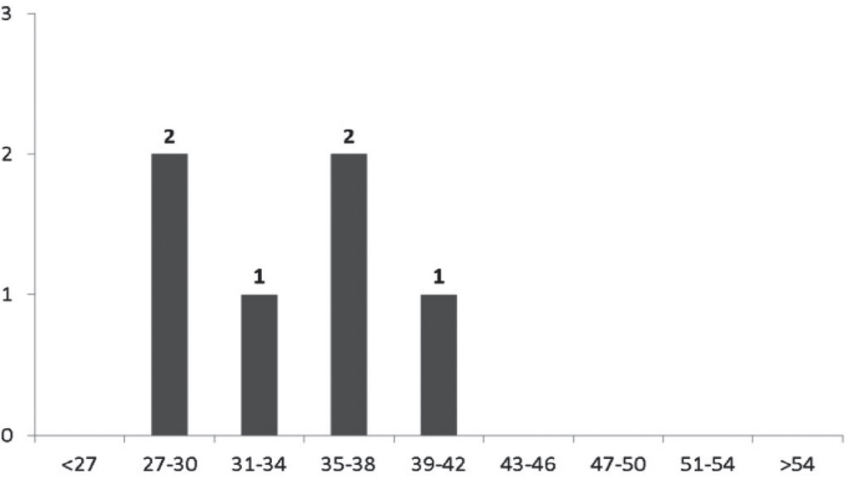

Triticum durum
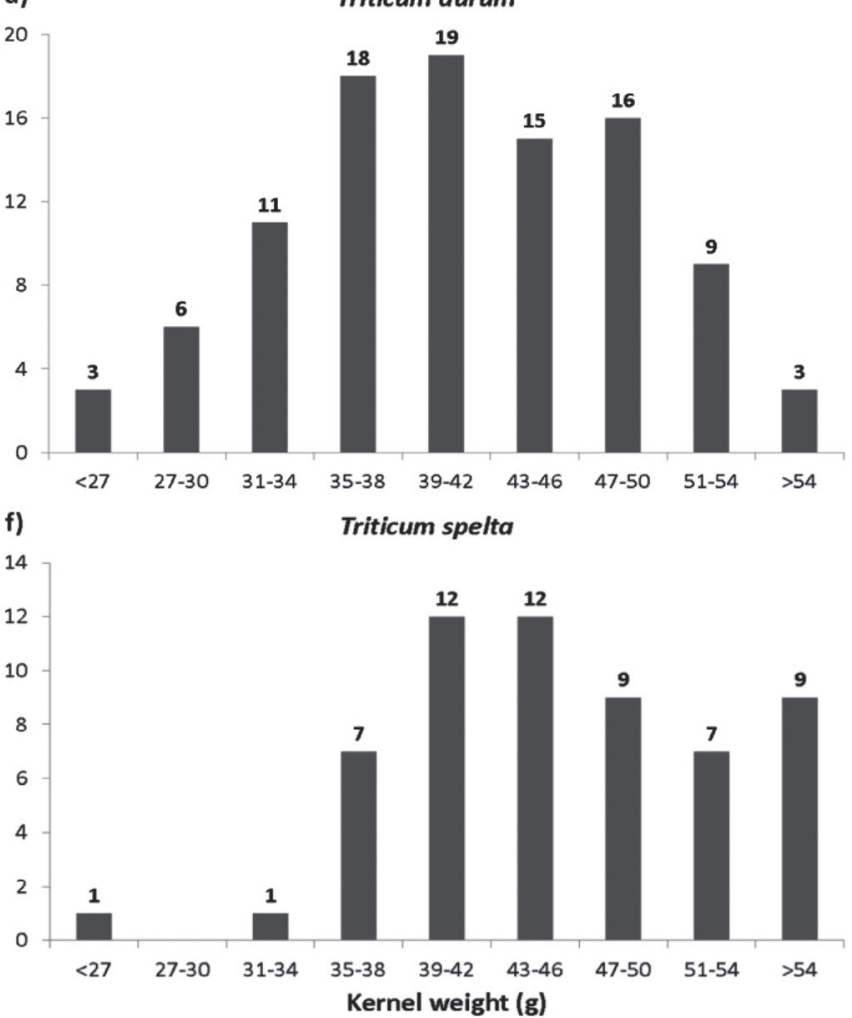

Figure 2. Distribution of thousand kernel weights of (a) Triticum monococcum, (b) T. dicoccoides, (c) T. dicoccum, (d) T. durum, (e) T. turgidum and (f) T. spelta. 

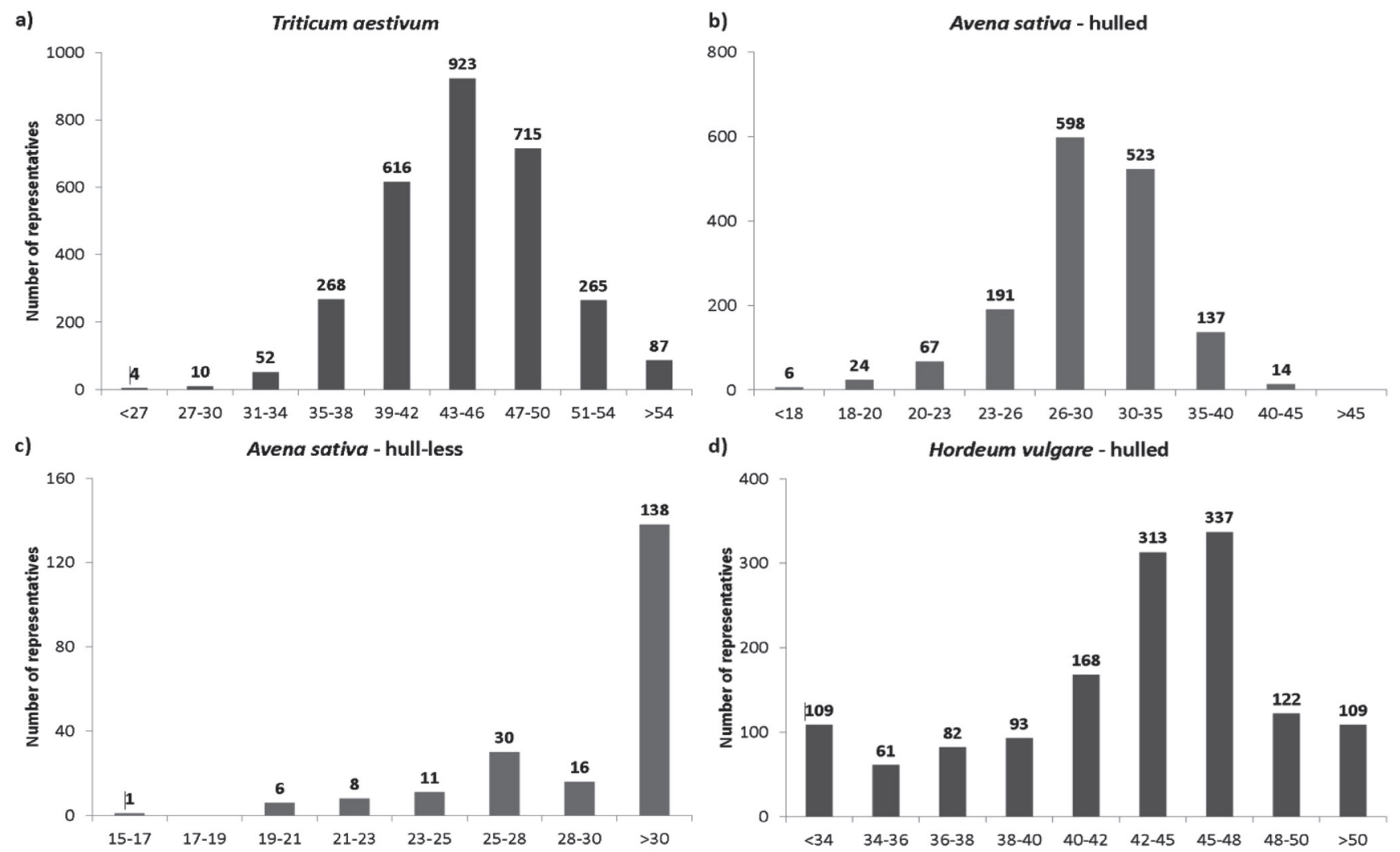

d) Hordeum vulgare - hulled
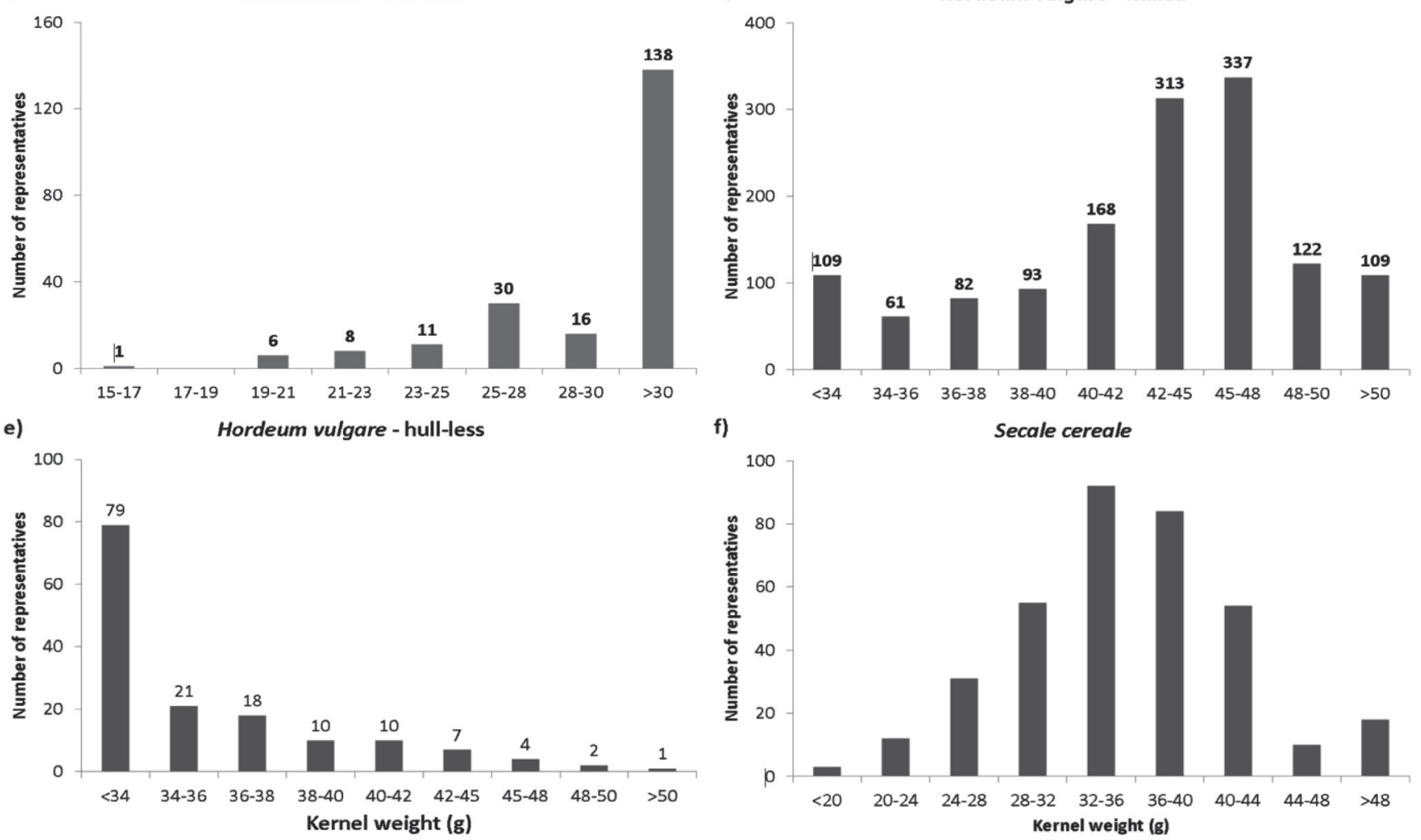

Figure 3. Distribution of thousand kernel weights of (a) Triticum aestivum, (b) hulled Avena sativa, (c) naked A. sativa, (d) hulled Hordeum vulgare, (e) naked $H$. vulgare and (f) Secale cereale.

species, we calculated the mean and median values, standard deviation (SD) and their coefficients in their relation to T. aestivum based on their mean and median values. We used the TKW of T. aestivum as the standard for our comparison with other cereal species because $T$. aestivum is the most important cereal species in widespread use today. Therefore, the coefficients were calculated as a ratio of the TKW of a particular cereal species to the TKW of T. aestivum.

\subsection{An example of grains in an archaeological assemblage}

A practical application of the recalculation coefficient can be well demonstrated with an archaebotanical assemblage, because in the prehistory of Europe, before written historical records, our knowledge of particular cereal values is exclusively based on archaeobotanical assemblages. The model assemblage consists of the analyzed macroremains of cereals gained during the archaeological excavations of the Late Bronze Age sites in the Bechyně region (South Bohemia, Czech Republic, altitude approx. $450 \mathrm{~m}$ asl). To demonstrate the importance of recalculation coefficients, grain samples from three settlements were used: Černýšovice - stage Br D - stages according to Jirán̆ (2008), $13^{\text {th }}$ century BC, Hvožd'any - stage Ha A2, $11^{\text {th }}$ century BC and Březnice - stage Ha A2/B1, 1050-1000 BC. Twenty contexts (146 samples, 1556 litres of feature infills and cultural layers) were analysed (for details, see Chvojka et al. 2011; Chvojka, Š́lková 2012). Macroremains were determined based on basic literature (Hajnalová 1999; Jacomet 2006) and the reference collection of the Laboratory of Archaeobotany 
Figure 4. Distribution of thousand kerne weights of Panicum miliaceum.

\section{Panicum miliaceum}

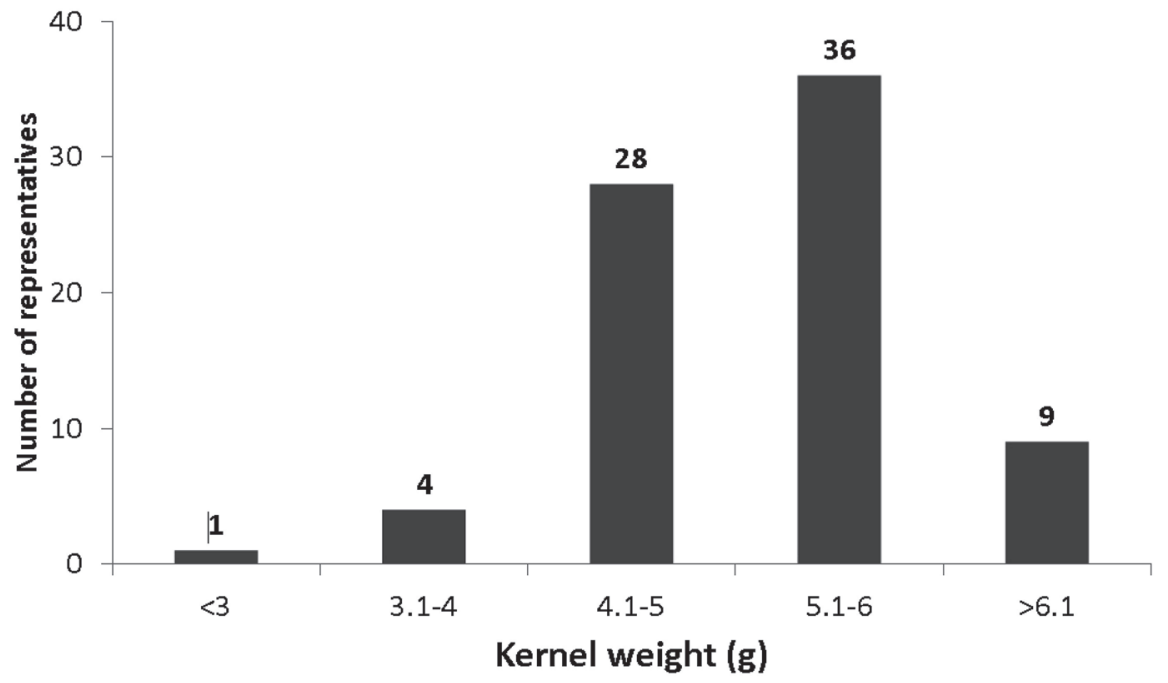

and Paleoecology, University of South Bohemia in České Budějovice. The Number of Identified Specimens (NISP) of caryopsis and rachis were counted. Data were transformed; inaccurate identifications were counted (e.g. Triticum cf. spelta was counted as T. spelta; Triticum spelta/dicoccum were divided based on their real proportion in studied sites). Naked Triticum caryopses were considered as T. aestivum in this study. The proportions of grains of different species were presented as percentages of the total number of recorded cereal grains for all three studied localities together.

\section{Results}

\subsection{The thousand kernel weights of different cereals}

The highest TKW from all the investigated cereal species was recorded for both the hexaploid wheat species $T$. spelta and $T$. aestivum followed by the tetraploid T. turgidum. The median values of TKW were the same $(44.5 \mathrm{~g})$ for all the above-mentioned Triticum species. The mean TKW of other cereal species decreased in the following order: hulled $H$. vulgare $>T$. durum $>T$. dicoccum $>$ hull-less $H$. vulgare $>$ $S$. cereale $>T$. dicoccoides $>T$. monococcum $>$ hulled $A$. sativa $>$ hull-less $A$. sativa $>P$. miliaceum. The median values of TKW were similar with the mean values for the majority of species and therefore recalculation coefficients based on mean and median values were almost the same (Table 1). There was high variability in the TKW for all the studied species (Figures 2-4). We recorded almost a normal distribution for the TKW of T. durum, T. spelta, T. aestivum, hulled $A$. sativa, $S$. cereale and $P$. miliaceum. Highly positively-skewed distributions were found for the TKW of T. monococcum and hull-less H. vulgare. On the other hand,

Table 1. Thousand kernel weight (TKW - weight of thousand caryopses) of cereals obtained from the literature and database Evigez. $\mathrm{n}$ - number of cases, mean - mean value of TKW, mean coef. - coefficient for comparison of different cereals based on mean TKW, median - median value of TKW, median coef. - coefficient for comparison of different cereals based on median TKW, SD - standard deviation.

\begin{tabular}{|c|c|c|c|c|c|c|}
\hline & $\mathbf{n}$ & Mean (g) & Mean coef. & Median (g) & Median coef. & SD \\
\hline Triticum aestivum & 2940 & 44.62 & 1 & 44.5 & 1 & 5.03 \\
\hline T. monococcum & 35 & 30.09 & 0.67 & 28.8 & 0.65 & 5.95 \\
\hline T. dicoccoides & 6 & 33.83 & 0.76 & 34.5 & 0.78 & 1.98 \\
\hline T. dicoccum & 80 & 39.45 & 0.88 & 39.35 & 0.88 & 5.08 \\
\hline T. durum & 100 & 41.14 & 0.92 & 40.5 & 0.91 & 7.43 \\
\hline T. turgidum & 23 & 44.28 & 0.99 & 44.5 & 1 & 8.23 \\
\hline T. spelta & 61 & 44.75 & 1 & 44.5 & 1 & 0.87 \\
\hline hulled Avena sativa & 1560 & 29.6 & 0.66 & 28 & 0.63 & 4.33 \\
\hline naked $A$. sativa & 210 & 28.44 & 0.64 & 30 & 0.67 & 2.75 \\
\hline hulled Hordeum vulgare & 1394 & 43.12 & 0.97 & 43.5 & 0.98 & 4.78 \\
\hline naked $H$. vulgare & 152 & 36.35 & 0.81 & 34 & 0.76 & 3.68 \\
\hline Secale cererale & 359 & 35.35 & 0.79 & 34 & 0.76 & 6.32 \\
\hline Panicum miliaceum & 78 & 5.17 & 0.12 & 5.17 & 0.12 & 0.72 \\
\hline
\end{tabular}


a highly negatively-skewed distribution was found for the TKW of hull-less $A$. sativa.

\subsection{Example of grains in archaeological assemblage}

In the original data obtained from three Late Bronze Age sites, $P$. milliaceum represented $51 \%$ of all cereal caryopses, but after recalculation, it was only $12 \%$ (Figure 5 ). As the proportion of $P$. milliaceum decreased substantially after recalculation, the importance of other cereal species increased: $H$. vulgare from $19 \%$ to $36 \%, T$. dicoccum from $18 \%$ to $31 \%$, T. spelta from $6 \%$ to $11 \%$, T. monococcum from $3 \%$ to $4 \%$, T. aestivum from $2 \%$ to $4 \%$, Avena $s p$. from $0.3 \%$ to $0.4 \%$ and $S$. cereale from $0.1 \%$ to $0.2 \%$.

\section{a) Original data}

Triticum monococcum; 3\% Avena sp.; 0.3\%

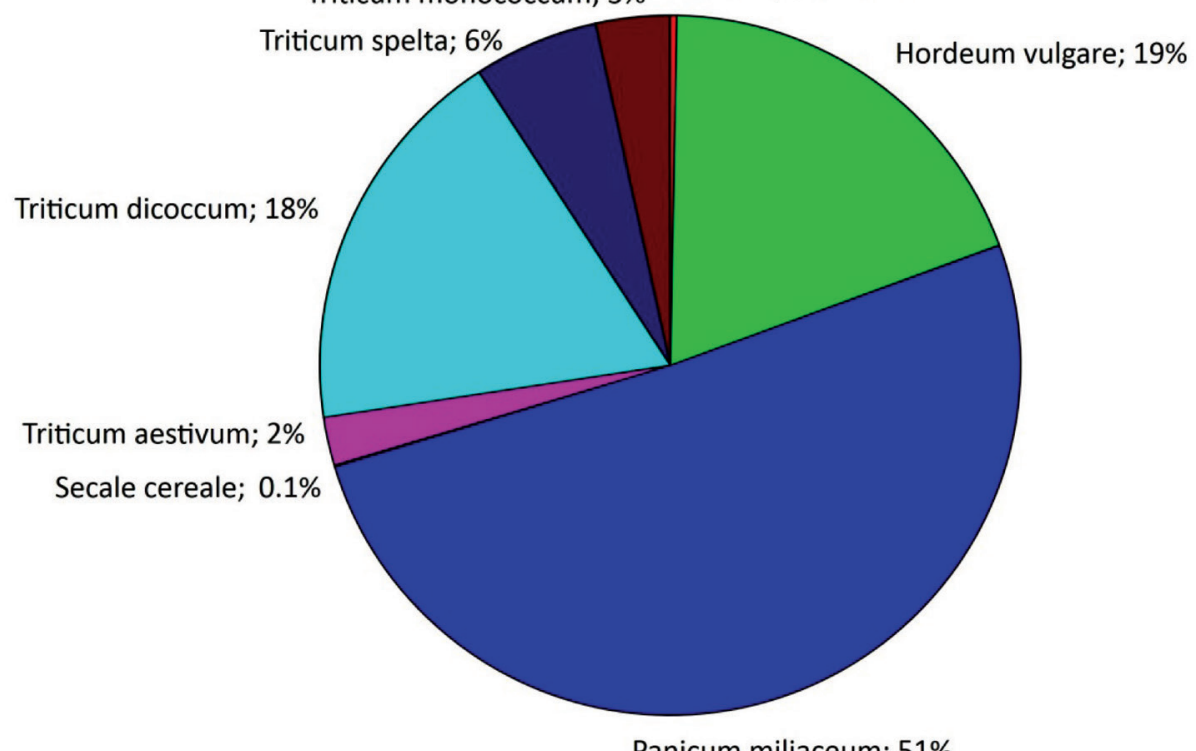

Panicum miliaceum; 51\%

\section{b) Recalculated data}

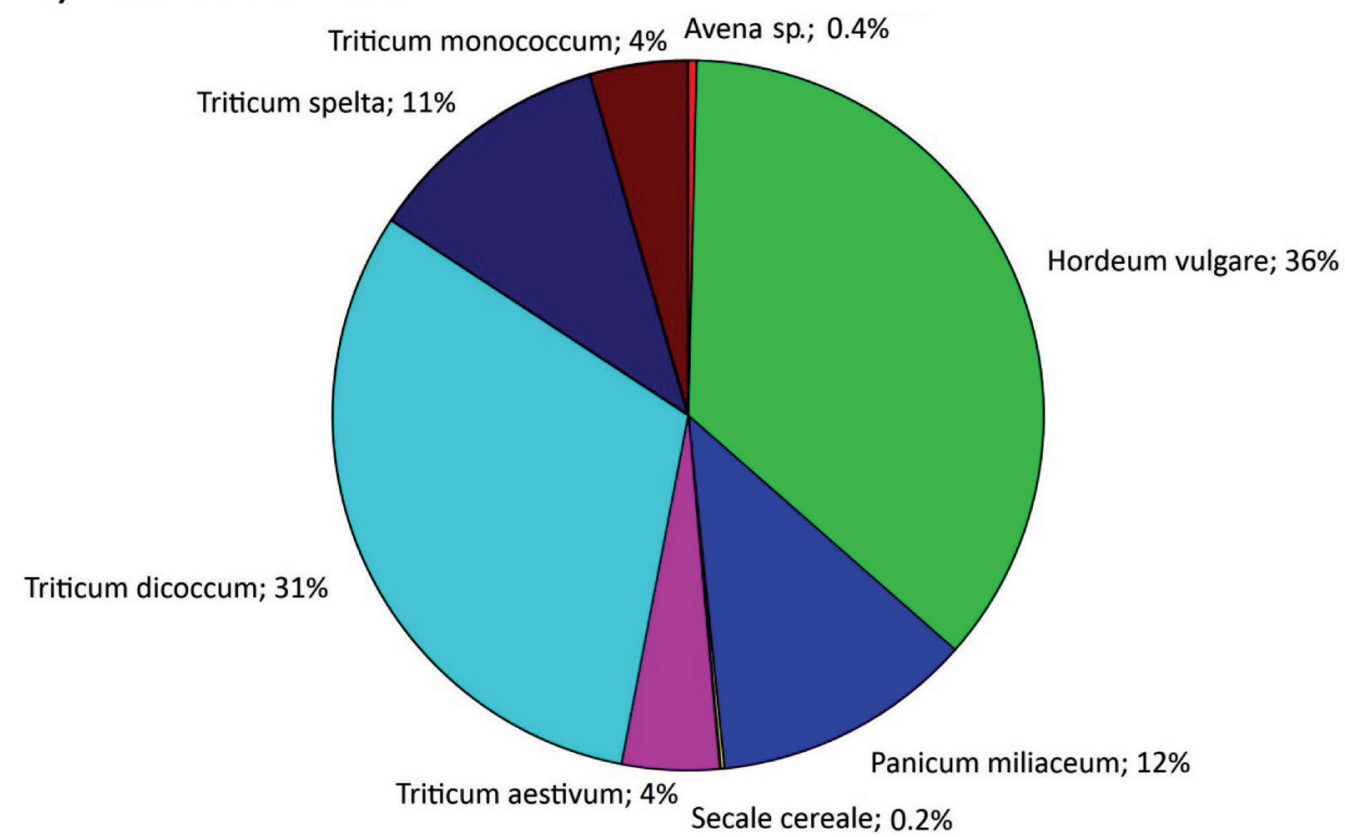

Figure 5. Proportion of grains of individual species from total number of cereal grains in the archaeological assemblage from the Late Bronze Age based on a) original proportions of grains and b) recalculated according to proposed coefficients. Coefficients for hulled varieties were applied for recalculations of Avena sativa and Hordeum vulgare. 


\section{Discussion}

The main message of our study is that there are large differences in kernel weights among the basic cereal species planted in Europe. We thus recommend the use of recalculation coefficients based on the weight of grains of the different cereal species in studies of their importance for human economies and human and animal nutrition. As the recalculation coefficients based on mean and median values of TKW were almost the same for all species, we recommend to use mean values: the mean is a generally better-known and more widely-used statistical value than the median. Taking the TKW of T. aestivum (44.6 g) as 100\%, the cereal species in relation to T. aestivum according to their TKW, in descending order, is the following: T. spelta (100\%), T. turgidum (99\%), hulled $H$. vulgare $(97 \%)$, T. durum (92\%), T. dicoccum (88\%), naked $H$. vulgare $(81 \%), S$. cereale $(79 \%)$, T. dicoccoides (76\%), T. monococcum (67\%), hulled A. sativa (66\%), naked A. sativa (64\%) and, finally, P. miliaceum (12\%). It can be argued that there is high variability in the kernel weights within each cereal species and that recalculation coefficients are therefore not sufficiently accurate. However, the answer is that though there was really high variability in kernel weights within each cereal species, the mean values of TKW characterize the grain weight of each species relatively well as the mean and median values were almost the same. In spite of these potential limits, it is hard to find a better parameter than TKW as an estimator of crop yield, and hence suitable for comparison of the importance of different cereal species in human subsistence. Recalculation coefficients are particularly important in cases where there is a high proportion of $P$. miliaceum in the archaeological assemblage, as its grain size differs the most from other frequently recorded cereals. This was well demonstrated using the example from the Late Bronze Age: without recalculation, the most important seemed to be $P$. miliaceum, but after recalculation, it proved to be $H$. vulgare followed by $T$. dicoccum, and the importance of $P$. miliaceum decreased more than four times. There are two main sources of variability in TKW within each species: (1) genetic; and (2) phenotypic plasticity. (1) The genetic component is highly important as there are known varieties, or landraces, with both low and high kernel weights. For example, the TKW of $T$. monococcum is higher in Mediterranean countries than in central European countries. The mean TKWs of T. monococcum landraces from Austria and Morocco planted together on the same locality were 25 and $36 \mathrm{~g}$, respectively (Brandolini et al. 2013). A similar gradient can be recorded as well for $T$. dicoccum. In the Czech Republic, for example, the mean TKW of $T$. dicoccum landraces ranged approximately from 31 to $34 \mathrm{~g}$ (Konvalina et al. 2012b; 2012c) compared to a mean value of $39 \mathrm{~g}$ recorded by De Vita et al. (2006) or $48 \mathrm{~g}$ recorded by Marino et al. (2011) in Italy. These south-north differences in the grain weights of landraces of different cereal species indicate that the recalculation coefficients can be potentially made more precise by using the Mediterranean and central European landraces and varieties separately; but this requires further in-depth research. In both T. mocococcum and T. dicoccum, there exist landraces with extraordinary high TKWs, but such landraces are rare (see Figures $2 \mathrm{a}$ and $2 \mathrm{c}$ ). Evidently, there was a long-term selection for TKW in both species dependent on latitude - bigger grains in the Mediterranean compared to northern regions. In addition, selection for the extraordinary high TKW was probably not undertaken, as the grain yield per area cannot be a positive function of TKW because of the very high grain yield compensation ability in both species. High grain yields can also be achieved with small grains but with high grain numbers per area (see Hejcman, Hejcmanová 2015 for grain yield compensation ability of $T$. dicoccum and T. aestivum). Whether the same north-south gradient of TKW in T. monococcum and T. dicoccum also existed in different historical periods has, according to the information of the authors, never been studied. As landraces of T. dicoccum, but also $H$. vulgare, might retain a phylogeographical structure that reflects ancient events (Saisho, Purugganan 2007; Isaac et al. 2010), we believe that the north-south gradient of TKW can also be recorded for grains from different historical periods, but this hypothesis requires further testing using ancient grains.

There also exists high phenotypic plasticity in the TKW. For instance, in the experiment by Hlisnikovský et al. (2015), the TKW ranged from 39.5 to $53.5 \mathrm{~g}$ for the same variety of $T$. aestivum. High TKWs were recorded under high $\mathrm{N}$-application regimes under optimum water supply and low TKWs were recorded under no fertilizer application in an extraordinary dry year. There were also differences in TKW between localities with different soil types. Hejcman, Hejcmanová (2015) recorded low TKW for $T$. dicoccum $(25 \mathrm{~g})$ in stands with a high seeding rate and therefore with too a high spike density.

\section{Conclusion}

Despite the high variability in TKW within each cereal species, we believe that the proposed recalculation coefficients for the comparison of grains of different cereal species are meaningful and correct as they are based on a meta-analysis of large amounts of available data from the available literature and records from the Evigez database, and not just on a single experiment with a restricted number of genotypes for individual cereal species. We recommend the use of these proposed recalculation coefficients for the comparison of proportions of cereal grains in archaeobotanical assemblages. The recalculated values better reflect the importance of different cereal species for human and animal nutrition, as opposed to the simple proportions of recorded grains of individual species from their total amounts.

\section{Acknowledgement}

The research was supported by projects NAZV QJ1210211, CIGA 20144207, RO0415 and PAPAVER CZ.1.07/2.3.00/20.0289. 


\section{References}

ARDUINY, I., MASONI, A., MARIOTTI, M., PAMPANA, S., ERCOLI, L. 2014: Cadmium uptake and translocation in durum wheat varieties differing in grain-Cd accumulation. Plant, Soil and Environment 60, 43-49.

BENEŠ, J., KOČÁR, P. 2000: Novověké obilnářství vsi Lažiště (okr. Prachatice) v Pošumaví na základě archeobotanické makrozbytkové analýzy. Archeologické výzkumy v jižních Čechách 13, 185-196.

BENEŠ, J., P̌̌IKRYLOVÁ, P. 2008: Analýza uhliků a zuhelnatělých rostlinných makrozbytků ze sídliště mladši doby bronzové v Hostivici u Prahy. LAPE, České Budějovice - Praha.

BERNARDOVÁ, A., KOMÁRKOVÁ, V., PROSTŘEDNÍK, J., BENEŠ, J. 2010: Fragmented barley grains from the Late Bronze Age TurnovMaškovy zahrady site in North Bohemia. Interdisciplinaria Archaeologica - Natural Sciences in Archaeology I/1-2/2010, 37-44.

BRANDOlini, A., HIDAlGO, A., PlizZARI, L., ERBA, D. 2011: Impact of genetic and environmental factors on einkorn wheat (Triticum monococcum L. subsp. monococcum) polysaccharides. Journal of Cereal Science 53, 65-72.

BRANDOLINI, A., HIDAlGO, A., VACCINO, P., PLIZZARI, L. 2013: Phenotypic variation of a Triticum monococcum L. core collection. Poster presented at the EUCARPIA Genetic Resources section meeting, 11-13 June 2013, Alnarp, Sweden.

BROMBACHER, C., HECKER, D. 2015: Agriculture, food and environment during Merovingian times: plant remains from three early medieval sites in northwestern Switzerland. Vegetation History and Archaeobotany 24,331-342.

CHVOJKA, O., BENEŠ, J., FRÖLICH, J., JOHN, J., MICHÁLEK, J., ŠÁlKOVÁ, T., BERNARDOVÁ, A., HOUFKOVÁ, P., KŘIVÁNEK, R., MAJER, A., NOVÁK, J., NOVÁKOVÁ, K., TALAROVIČOVÁ, E. 2011: Osídlení doby bronzové v povodí říčky Smutné v jižních Čechách. Archeologické výzkumy v jižních Čechách. Supplementum 8, 308-325.

CHVOJKA, O., ŠÁLKOVÁ, T. 2012: Zur Deutung der urnenfelderzeitlichen streifenformigen Siedlungsobjekte. In: Peregrinationes archaeologicae in Asia et Europa Joanni Chochorowski dedicatae. 183-191.

CODIANNI, P., RONGA, G., DI FONZO, N., TROCCOLI, A. 1996 Performance of selected strains of 'farro' (Triticum monococcum L., Triticum dicoccum Schübler, Triticum Spelta L.) and durum wheat (Triticum Durum Desf. cv. Trinakria) in the difficult flat environment of Southern Italy. Journal of Agronomy and Crop Science 176, 15-21.

DE VITA, P., RIEFOLO, C., CODIANNI, P., CATTIVELLI, L., FARES, C. 200: Agronomic and qualitative traits of T. turgidum ssp. dicoccum genotypes cultivated in Italy. Euphytica 150, 195-205.

DRESLEROVÁ, D., KOČÁR, P. 2013: Trends in cereal cultivation in the Czech Republic from the Neolithic to the Migration period (5500 B. C. A. D. 580). Vegetation History and Archaeobotany 22,257-268.

DRESLEROVÁ, D., KOČÁR, P., CHUMAN, T., ŠEFRNA, L., PONIŠTIAK, Š. 2013: Variety in cereal cultivation in the Late Bronze and Early Iron Ages in relation to environmental conditions. Journal of Archaeological Science 40, 1988-2000.

FESTI, D., TECCHIATI, U., STEINER, H., OEGGL, K. 2011: The Late Neolithic settlement of Latsch, Vinschgau, northern Italy: subsistence of a settlement contemporary with the Alpine Iceman, and located in his valley of origin. Vegetation History and Archaeobotany 20, 367-379.

GUARDA, G., PADOVAN, S., DELOGU, G. 2004: Grain yield, nitrogenuse efficiency and baking quality of old and modern Italian breadwheat cultivars grown at different nitrogen levels. European Journal of Agronomy 21, 181-192.

HAJNALOVÁ, E. 1993: Obilie v archeobotanických nálezech na Slovensku. Acta Interdisciplinaria Archaeologica VIII, Nitra.

HAJNALOVÁ, E. 1999: Archeobotanika pestovaných rastlin. Slovenská pol'nohospodárska univerzita, Nitra.

HEJCMAN, M., HEJCMANOVÁ, P. 2015: Yield and nutritive value of grain, glumes and straw of Triticum dicoccum produced by prehistoric technology in comparison to T. aestivum produced by modern technology. Interdisciplinaria Archaeologica, Natural Sciences in Archaeology $\mathrm{VI} / 1 / 2015,31-45$.

HLÍNIKOVSKÝ, L., KUNCOVÁ, E., HEJCMAN, M., DVOŘÁČEK, V. 2015: Effect of fertilizer application, soil type, and year on yield and technological parameters of winter wheat (Triticum aestivum) in the Czech Republic. Archives of Agronomy and Soil Science 61, 33-53.

ISAAC, A. D., MULDOON, M., BROWN, K. A., BROWN, T. A. 2010: Genetic analysis of wheat landraces enables the location of the first agricultural sites in Italy to be identified. Journal of Archaeological Science 37, 950-956.

JACOMET, S. 2006: Identification of cereal remains from archaeological sites. $2^{\text {nd }}$ edition. Basel.

JIRÁŇ, L. (Ed.) 2008: Archeologie pravěkých Čech - Svazek 5. Doba bronzová. Archeologický ústav AV ČR, Praha.

KARAGÖZ, A., ZENCIRCI, N. 2005: Variation in wheat (Triticum spp.) landraces from different altitudes of three regions of Turkey. Genetic Resources and Crop Evolution 52, 775-785.

KOČÁR, P., DRESLEROVÁ, D. 2010: Archaeobotanical finds of cultivated plants in the prehistory of the Czech Republic. Pamatky archeologické 101, 203-242.

KONVALINA, P., CAPOUCHOVÁ, I., STEHNO, Z. 2012a: Agronomically important traits of emmer wheat. Plant, Soil and Environment 58, 341-346. KONVALINA, P., CAPOUCHOVÁ, I., STEHNO, Z., KÁŠ, M., JANOVSKÁ, D., ŠKEŘIIKOVÁ, A., MOUDRÝ, J. 2012c: Pěstováni a využití pšenice dvouzrnky v ekologickém zemédělství. Výzkumný ústav rostlinné výroby, Praha.

KONVALINA, P., CAPOUCHOVÁ, I., STEHNO, Z., MOUDRÝ, J. 2012b: Differences in yield parameters of emmer in comparison with and new varieties of bread wheat. African Journal of Agricultural Research 7, 986-992.

KREUZ, A., MARINOVA, E., SCHÄFER, E., WIETHOLD, J. 2005: A comparison of early Neolithic crop and weed assemblages from the Linearbandkeramik and the Bulgarian Neolithic cultures: differences and similarities. Vegetation History and Archaeobotany 14, 237-258.

LISTER, D. L., JONES, M. K. 2013: Is naked barley an eastern or a western crop? The combined evidence of archaeobotany and genetics. Vegetation History and Archaeobotany 22, 439-446.

MARINO, S., TOGNETTI, R., ALVINO, A. 2009: Crop yield and grain quality of emmer populations grown in central Italy, as affected by nitrogen fertilization. European Journal of Agronomy 31, 233-240.

MARINO, S., TOGETTI, R., ALVINO, A. 2011: Effects of varying nitrogen fertilization on crop yield and grain quality of emmer grown in a typical Mediterranean environment in central Italy. European Journal of Agronomy 34, 172-180.

PAGNOTTA, M. A., MONDINI, L., CODIANNI, P., FARES, C. 2009: Agronomical, quality, and molecular characterization of twenty Italian emmer wheat (Triticum dicoccon) accessions. Genetic Resources and Crop Evolution 56, 299-310.

PELEG, Z., FAHIMA, T., KOROL, A. B., ABBO, S., SARANGA, Y. 2011: Genetic analysis of wheat domestication and evolution under domestication. Journal of Experimental Botany 62, 5051-5061.

PREISS, S., MATTERNE, V., LATRON, F. 2005: An approach to funerary rituals in the Roman provinces: plant remains from a Gallo-Roman cemetery at Faulquemont (Moselle, France). Vegetation History and Archaeobotany 14, 362-372.

TROCCOLI, A., CODIANNI, P. 2005: Appropriate seeding rate for einkorn, emmer, and spelt grown under rainfed condition in southern Italy. European Journal of Agronomy 22, 293-300.

SAISHO, D., PURUGGANAN, M. D. 2007: Molecular phylogeography of domesticated barley traces expansion of agriculture in the old world. Genetics 177, 1765-1776.

ŠÁLKOVÁ, T., BENEŠ, J., KOMÁRKOVÁ, V., VANĚČEK, Z. 2012: History of barley (Hordeum vulgare) in Central Europe according to archaeobotanical findings. Kvasný prưmysl 58, 215-227.

ÜNAL, H. G. 2009: Some physical and nutritional properties of hulled wheat. Tarim bilimleri dergisi 15, 58-64.

ZAHARIEVA, M., AYANA, N. G., AL HAKIMI, A., MISRA, S. C., MONNEVEUX, P. 2010: Cultivated emmer wheat (Triticum dicoccon Schrank), an old crop with promising future: a review. Genetic Resources and Crop Evolution 57, 937-962.

ZAHARIEVA, M., MONNEVEUX, P. 2014: Cultivated einkorn wheat (Triticum monococcum L. subsp. monococcum): the long life of a founder crop of agriculture. Genetic Resources and Crop Evolution 61, 677-706.

ZOHARY, D., HOPF, M., WEISS, E. 2012: Domestication of plants in the old world, 4th edition. Oxford University Press, Oxford. 